\title{
WSPÓŁDECYDOWANIE W POLITYCE PUBLICZNEJ
}

\section{CO-DECIDING IN PUBLIC POLICY}

The main aim of the article is to emphasize those reasons of the development barriers which are related to the shortcomings of deliberative co-decisional practices in public policy. The author assumes the culturally-institutional and functional methodological orientation and refers to examples of the Polish social dialogue, civil dialogue, lobbying, public hearing and social consultations.

Słowa kluczowe: polityka publiczna, deliberacja, pułapka średnich dochodów Key words: public policy, deliberation, middle income trap

* Prof. dr hab. Jacek Sroka, Uniwersytet Pedagogiczny im. Komisji Edukacji Narodowej w Krakowie, almond351@gmail.com, https://orcid.org/0000-0002-4432-3720

I. WSTĘP

utor wyszedł założenia, że wykonawczo-administracyjny elitaryzm (hierarchia) porządkuje i podporządkowuje przeciwieństwa interesów grupowych, demokratyczna reprezentacja (parlament) je wyodrębnia, wysłuchuje i porównuje, a współdecydująca deliberacja jako poszerzona o emocje i korzyści wiedza swoista demokratyczna gnoza (episteme) przeciwieństwa te jest w stanie komunikować i przynajmniej tymczasowo — godzić w toku debat i współpracy bardziej wprawdzie żmudnych, ale także bardziej skutecznych w porównaniu z dwoma wcześniej wymienionymi porządkami ${ }^{1}$.

Zamkniętą w tym akapicie tezę autor rozwinął, ale nie poddał jej ostatecznej weryfikacji. Zajęłoby to zbyt wiele miejsca, poza tym problematyka ta jest stale poddawana dyskusji, której końca - jak dotąd - nie widać. Pojawiają się w niej wciąż nowe wątki i problemy. Jednym z takich problemów jest tzw. pułapka średnich dochodów, której w artykule poświęcono uwagę, bez zamiaru ostatecznego rozstrzygnięcia pytań, które w związku z nią się pojawiają. Nie znaczy to zarazem, że w artykule brakuje sugestii odpowiedzi służących obronie hipotezy zawartej w tytule. Chodzi o argumenty nawiązujące do dialogu społecznego, dialogu obywatelskiego, deliberacji, lobbingu, wysłuchania publicznego i konsultacji społecznych. Głównym celem autora tekstu nie było jednak — jak wspomniano - autorytatywne rozstrzyganie, ale deliberacyjna inspiracja. Starając się uwypuklić znaczenie podniesionego problemu, autor zastosował kompilację elementów analizy funkcjonalnej i neo-instytucjonalnej, utrzymaną w konwencji tzw. teorii średniego zasięgu o orientacji wdrożeniowej, która jest charakterystyczna dla studiów z zakresu polityki publicznej. Tekst nie ma zatem charakteru prawniczego, nie zawarto w nim omówienia aktów prawnych,

1 J. Sroka, Współdecydowanie w wielopasmowej polityce publicznej, Warszawa 2018, s. 90. 
do których w kilku miejscach jedynie się odwołano, ani pojęcia „deliberacji”, mimo że ściśle przynależy ono do kręgu analiz polityki publicznej, to jednak zajęłoby to zbyt wiele miejsca. Poza tym tematyce tej poświęcono odrębne monografie autorskie ${ }^{2}$.

Na potrzeby niniejszego tekstu dość będzie powiedzieć, że deliberacja jest najbardziej zaawansowaną formą dialogowego współdecydowania, w którym konsensualnie nastawione strony razem i dobrowolnie działają na rzecz wypracowywania nowej, wspólnej wiedzy (episteme) i wdrażania — zgodnie z tą wypracowaną wspólnie wiedzą — decyzji pomnażających jednostkowe i grupowe szanse, a także zasoby o charakterze wspólnotowym (tzw. wspólne pastwiska ${ }^{3}$ ). Deliberujące strony szanują swoją autonomię i nie abstrahują od swych wzajemnych interesów, a także od eksperckiej, jak również laickiej wiedzy oraz od jednostkowych i grupowych emocji.

Tak rozumiana deliberacja złudzeniem nie jest, co dla wielu może zakrawać na demokratyczną fatamorganę. Jest to realna praktyka decyzyjna w wielu krajach, nie tylko w tych, którym nie grozi pułapka średnich dochodów, ale i w tych, w których do osiągnięcia średnich dochodów dopiero się aspiruje ${ }^{4}$. Deliberacja — zgodnie z argumentacją zawartą w niniejszym tekście — również stanowi skuteczne remedium na tę przypadłość. Wykorzystanie deliberacyjnej ścieżki wychodzenia z rozwojowej pułapki średnich dochodów wymaga jednak istotnego wysiłku od wszystkich zaangażowanych stron. Ze względu na uwarunkowania przeszłości oraz niedostatki wysiłek ten nie zawsze jest możliwy.

\section{ZALEŻNOŚĆ OD WYBORU ŚCIEŻKI I PUŁAPKA ŚREDNICH DOCHODÓW}

Mając na uwadze tzw. pułapkę średnich dochodów, o której istocie będzie jeszcze mowa, można stwierdzić, że prawdziwe, pełne, niekłamane współdecydowanie, którego istotą jest deliberacja, jawi się jako ścieżka, której wybór daje relatywnie największe szanse na wyjście z zaanonsowanego w tytule średniodochodowego potrzasku rozwojowego. Poruszany problem jest ważny i powinien być rozpatrywany zarówno przez gremia reprezentatywne, $w$ tym przede wszystkim parlament i władzę wykonawczą, ale także władzę sądowniczą oraz - co jest zdecydowanie nie mniej ważne — przez gremia dialogowe, w których (przynajmniej nominalnie) odbywa się współdecydowanie. Tymczasem z wielu współczesnych — zarówno „dzisiejszych”, jak i „wczorajszych” — krajowych wypowiedzi można niekiedy wysnuć wniosek, że pułapka średnich

${ }^{2}$ Vide J. Sroka, Deliberacja i rzadzenie wielopasmowe, Wrocław 2009, s. 7 i n.; idem, Współdecydowanie $w$ wielopasmowej..., s. 7 i n.

3 Vide G. Hardin, The Tragedy of the Commons, „Science. New Series” 1968, t. 162, nr 3859, s. 1243 i n.

${ }^{4}$ Vide J.J. Mansbridge, K. Flaster, The Cultural Politics of Everyday Discourse: The Case of “Male Chauvinist”, „Critical Sociology” 2007, nr 33, s. 627 i n.; R.C.M. Maia, C. Danila, J.K.R. Bargas, V.V. Oliveira, P.G.C. Rossini, R.C. Sampaio, Authotrity and Deliberative Moments: Assessing Equality and Inequality in Deeply Divided Groups, „Journal of Public Deliberation” 2017, nr 2, s. 1 i n.; V.S.P. Coelho, A Brief Reflection on the Brazilian Participatory Experience, „Journal of Public Deliberation” 2014, nr 1, s. 4 i n.; K. Grönlund, K. Herne, M. Setälä, Does Enclave Deliberation Polarize Opinions?, „Political Behaviors" 2015, nr 37, s. 995 i n. 
dochodów to trącący myszką temat dla pesymistów, którego znaczenie przebrzmiewa wraz z pokonywaniem błędów i zaniechań znanych z bliższej lub dalszej, „słusznie minionej” przeszłości. Jawić się więc może ta pułapka jako zagrożenie przeszłe, dziś już pozorne, nawet zbyt nagłaśniane, a w istocie mało widoczne i istotne, $\mathrm{w}$ tym więc sensie „szklane”, nieistotne zarówno w poważnych parlamentarnych debatach legislacyjnych, w hierarchiczno-administracyjnych działaniach wdrożeniowych oraz w bardziej z nazwy - dialogowych przetargach interesów grupowych.

Uznając hierarchię, reprezentację i deliberację za słabo skomunikowane i w tym sensie rozbieżne drogi ucieczki z rodzimego wariantu pułapki średnich dochodów, można nawiązać do znanej koncepcji zależności od wyboru ścieżki (path dependency) ${ }^{5}$. W koncepcji tej zakłada się rzecz tak oczywistą, że wręcz zakrawającą na ,prawo żelazne", które w spłyconej wersji może nawet zabrzmieć jak truizm, a mianowicie, że trajektorie rozwojowe przyszłości są zależne od ścieżek obieranych w przeszłości. Jest to jasne i zgodne z potocznym doświadczeniem. Wiadomo bowiem, że wybór drogi się liczy i rzutuje na dalszy przebieg podróży, choćby z tego powodu, że przy drogach mało uczęszczanych trudniej o sklep, restaurację czy stację benzynową. Chodzi jednak również o rzecz na pierwszy rzut oka mniej już może oczywistą, ale nie mniej istotną — mianowicie o to, że każdy system złożony, każdy system o wielopunktowej równowadze — nie tylko system społeczny, gospodarczy czy polityczny, ale również złożony układ cen, płac, ofert kredytowych, programowych propozycji partyjnych, relacji przemysłowych, stosunków rodzinnych, towarzyskich czy profesjonalnych — może stabilizować się w różnych punktach skali: od optimum do pessimum. Możliwe jest więc i w sumie często spotykane - że zarówno układy relacji międzyludzkich, jak i systemy społeczno-gospodarczo-polityczne będą się rozwijać w kierunku gorszych standardów i standardy te w długich okresach będą — zarówno jednostkowo, jak i zbiorowo generalnie akceptowane i podtrzymywane, częściowo z nawyku, a po części z braku wyboru. Będzie się je akceptować, ulegając wygodzie wynikającej z lepszego położenia w ramach takiego układu, ale też ulegając inercji, jaką taki stan niesie, np. inercji, na którą składają się małe prywatne nieuczciwości albo mniej lub bardziej drobne oszustwa, które inercyjny stan umożliwią, ale także drobne zaniechania czy mało istotne rezygnacje z pewnych lepszych standardów, np. standardów estetycznych, jak w od niedawna naukowo diagnozowanych realiach tzw. brzydkich przedmieść 6 . Trwanie w podobnym stanie, akceptowanie jego zaniżonych standardów w długim, a nawet bardzo długim czasie może odbywać się nawet przy pełnej świadomości możliwości zaistnienia lepszych światów i to w sumie niespecjalnie wielkim kosztem, ale pod warunkiem zaakceptowania i podtrzymania nieco wyższych standardów, przy nieco większym

${ }^{5}$ Vide P.A. David, Path dependence, its critics and the quest for 'historical economics', [w:] Evolution and Path Dependence in Economic Ideas: Past and Present, red. P. Garrouste, S. Ioannides, Cheltenham 2000, s. 2 i n.; P. Pierson, Increasing Returns, Path Dependence and the Study of Politics, „American Political Science Review” 2000, nr 2, s. 251 i n.

${ }^{6}$ Vide K. Kajdanek, Dlaczego polskie przedmieścia sa tak chaotyczne i brzydkie?, <https://wszystko conajwazniejsze.pl>, dostęp 28 II 2019. 
wysiłku oraz z pewnym poskromieniem egoizmów indywidualnych i grupowych. Jest to kluczowy problem każdej zmiany kulturowej. Najoporniejsze z tych zmian potrafią zabierać całe stulecia, a wysiłki formalne przy całej komplikacji takiej reformistycznej sytuacji miewają niewielki pozytywny, a spory negatywny potencjał dla ostatecznego rezultatu. Taka nowa gra, gra w lepsze standardy wymaga solidarnego postępowania, odkurzenia kompetencji społecznych, wymaga prawdziwego, powszechnego i niestylizowanego przypomnienia sobie o empatii. Niszczącym ją zagrożeniem jest nieszczerość przejawiająca się m.in. wichrowatością relacji, czy ,jazdą na gapę”. Zatem aby powodzenie takiej zmiany było naprawdę prawdopodobne, możliwie wszystkim uczestnikom danego środowiska powinno się chcieć w tę zmodyfikowaną grę grać. Dlatego niemal nikt nie może się z niej w dłuższym okresie wyłamywać i to dobrowolnie. Dobrowolność jest jednym z najtrudniejszych elementów do spełnienia, ponieważ całość sytuacji nosi wyraźne znamiona znanego dylematu więźnia. To także główny powód, dla którego żyje się jak dotąd — wprawdzie „ciasno, ale własno”.

Co do wyborów złych, splątanych ścieżek w interesującym nas zakresie i w polskiej przeszłości stawia się kolejną tezę, że przeszłe decyzje odnoszące się do dialogu społecznego, dialogu obywatelskiego, lobbingu, ale także wysłuchania publicznego i konsultacji społecznych były interesownymi kalkulacjami politycznymi podejmowanymi na potrzeby chwili, bez cienia nawet kształtu komplementarnej wizji przyszłościowej $^{7}$. Ta sama uwaga jeszcze bardziej dotyczy deliberacji. Jest ona bowiem jeszcze gorzej rozumiana niż obie formy dialogu (tj. dialog społeczny i dialog obywatelski), lobbing, wysłuchanie publiczne czy konsultacje społeczne. Dlatego też elementy deliberacji były i są wprowadzane w sposób najbardziej chaotyczny i jedynie wtedy, gdy wymuszają to uwarunkowania polityk sektorowych Unii Europejskiej, jak to było i jest choćby w przypadku Zintegrowanego Systemu Kwalifikacji ${ }^{8}$, europejskich funduszy strukturalnych i inwestycyjnych $^{9}$ czy nauki i szkolnictwa wyższego ${ }^{10}$.

Pułapka średnich dochodów jest efektem z tej samej kategorii, którą oznacza pojemny termin path dependency, tzn. wynika z wcześniej dokonywanych wyborów tych decyzji gospodarczych, w których preferowano pierwsze zadowalające rozwiązania, np. rozwiązania aż nadto eksploatujące dostępność taniej pracy (uparcie

7 Vide Wybrane instytucje demokracji partycypacyjnej w polskim systemie politycznym, red. J. Sroka, Warszawa 2008, s. 6 i n.

8 J. Sroka, Rekomendacje $w$ zakresie zasad właczania interesariuszy do wspótpracy zmodernizowanym Systemie Kwalifikacji (Rada Interesariuszy), Warszawa 2015, s. 4 i n.; ustawa z dnia 22 grudnia 2015 r. o Zintegrowanym Systemie Kwalifikacji, Dz.U. z 2016 r. poz. 64.

9 J. Sroka, Czy nieformalne wzorce kulturowe oraz formalne instytucje nadażaja za potrzeba partnerstwa $i$ dialogu? Czy $i$ ewentualnie $w$ jaki sposób można wzmacniać potencjał strony społecznej $w$ ramach partnerstwa $i$ dialogu w europejskich funduszach strukturalnych $i$ inwestycyjnych?, ekspertyza przygotowana na zlecenie dolnośląskiej Wojewódzkiej Rady Dialogu Społecznego, maszynopis powielony, Wrocław 2016, s. 3 i n.; ustawa z dnia 11 lipca 2014 r. o zasadach realizacji programów w zakresie polityki spójności finansowanych w perspektywie finansowej 2014-2020, Dz.U. z 2014 r. — poz. 1146.

10 J. Sroka, Dialog w nauce i o nauce - o ograniczeniach polityki naukowej, „Cywilizacja i Polityka” 2017, nr 15; ustawa z dnia 20 lipca 2018 r. Prawo o szkolnictwie wyższym i nauce, Dz.U. z 2018 r. poz. 1668. 
i z pewną lubością wciąż nazywanej w Polsce siłą roboczą) czy generalnie niskich kosztów uzyskania. Widać - nie tylko z perspektywy lat, które od tych decyzji upłynęły (ponieważ mimo wygłaszanych derywacji uwidoczniało się to w zasadzie od razu) - że były to rozwiązania najbardziej oczywiste, jak również niewymagające specjalnego wysiłku intelektualnego i koncepcyjnego, nie mówiąc już o wysiłku kooperacyjnym, a tym bardziej o wysileniu empatii. Były to zarazem działania przynoszące wybranym bajeczny, a pozostałym w najlepszym razie niezbyt dobry, a nierzadko nawet tragiczny efekt ekonomiczny. Współczesnym rezultatem splotu tych przeszłych decyzji, a także zakorzenionych w przeszłości instytucjonalnych, strukturalnych i sytuacyjnych uwarunkowań jest właśnie pułapka średnich dochodów, zatrzymująca poszczególne gospodarki, m.in. gospodarkę polską, w licznej grupie państw o średnim poziomie dochodowym.

Zjawisko pułapki średnich dochodów uwypuklili w 2012 r. ekonomiści Banku Światowego Pierre-Richard Agénor, Otaviano Canuto i Michael Jelenic, w opracowaniu Avoiding Midle-Income Growth Trap ${ }^{11}$. W ślad za wspomnianymi oraz wieloma innymi badaczami pułapkę średnich dochodów uznaje się — jak już wspominano za sufit rozwojowy, którego sforsowanie jest tak trudne, że prawie niemożliwe. Sufit ten - choć dla urzędowo-optymistycznych albo nieuważnych obserwatorów bywa przejrzysty - jest jednak bardzo twardy. Przekonuje o tym uporczywy pat rozwojowy wielu krajów zbliżonych w swych charakterystykach — podobnie jak Polska do tzw. zależnych gospodarek wolnorynkowych o profilu hybrydowym i z przewagą cech śródziemnomorskiego wariantu ekonomii wolnego rynku ${ }^{12}$.

\section{ZALEŻNOŚĆ OD WYBORU ŚCIEŻKI I PULAPKA WSPÓLNYCH DECYZJI}

W okresie powojennym awans z grupy gospodarek uwięzionych w pułapce średnich dochodów udał się jedynie nielicznym krajom, np. Grecji i Irlandii. Grecję jednak ponownie zdeklasował kryzys, któremu skutecznie oparła się Irlandia, głównie dzięki wykorzystaniu bezprecedensowego przykładu deliberacji prowadzonej w niełatwych okolicznościach - w warunkach dominacji rywalizacyjnej kultury politycznej, bardziej sprzyjającej lobbingowi niż dialogowi. Mimo wspomnianej dominacji pluralistycznej kultury politycznej, która jest bliższa wariantowi brytyjskiemu niż kontynentalnemu, Irlandii od początku XXI w. udało się przełamać impas średnich dochodów w wyniku okiełznania konfliktogennych i niszczycielskich elementów rywalizacyjnej kultury politycznej. Tego przełomu dokonano za sprawą umiejętnie zarządzanej polityki publicznej, której rdzeniem jest praktyka deliberacyjnego kontraktowania paktów

${ }^{11}$ P.R. Agénor, O. Canuto, M. Jelenic, Avoiding Midle-Income Growth Trap, „Economic Premise” 2012, nr 98, s. 1 i n.

${ }_{12}$ Vide A. Nölke, A. Vliegenjhart, Enlarging the Varietes of Capitalism: The emergence of dependent market economies in East Central Europe, „World Politics” 2009, nr 4, s. 670; R. Rapacki, Czwarta rewolucja przemystowa a kierunki ewolucji kapitalizmu patchworkowego w Polsce, [w:] Świat (bez) pracy. Od Fordyzmu do czwartej rewolucji przemysłowej, red. J. Czarzasty, Cz. Kliszko, Warszawa 2018, s. 203 i n. 
społecznych ${ }^{13}$. Pakty angażują wszystkich istotnych interesariuszy w działania na rzecz realizacji innowacyjno-rozwojowych celów społecznych i gospodarczych. Ich realizacja każdorazowo - przy okazji kolejnych paktów - przybiera formę społecznego kontraktu o charakterze projektowym, ze wskazanymi dzięki deliberacji celami, z wyodrębnionymi w podobny sposób kryteriami ewaluacji, z metodami, narzędziami, wydzielonym budżetem oraz z profesjonalnym, opłacanym zarządem dysponującym odpowiednimi możliwościami wykonawczymi oraz kadrą, ponoszącym odpowiedzialność za realizowane przedsięwzięcia.

Deliberacyjna ścieżka wyjścia z pułapki średniego dochodu jest zatem skuteczna, co nie oznacza, że łatwa. Na tej ścieżce bowiem czyha kolejna zasadzka, zidentyfikowana pod koniec lat osiemdziesiątych przez Fritza Scharpfa jako pułapka wspólnych decyzji (joint-decision trap) ${ }^{14}$. To właśnie jej istnienie uzasadnia specyfikę kontraktowej irlandzkiej drogi wychodzenia z pułapki średniego dochodu. Istotą pułapki współdecydowania jest stałe zagrożenie patem decyzyjnym. Jest ono wprost proporcjonalne do poziomu autonomii uczestników, czego Scharpf dowiódł na przykładzie kompromisów niemieckiej federacji z landami, które mogą skutecznie blokować procesy legislacyjne, korzystając m.in. ze swych pozycji w Bundesracie, wyższej izbie niemieckiego parlamentu, ale także ze specyficznej siły oddziaływania banków landowych (Landesbank) w organizacyjnej strukturze Bundesbanku. Efekt ten stanowi o specyfice niemieckiego wariantu korporatystycznego ${ }^{15}$ współdecydowania, w którym nie ma wprawdzie znanej centralnej instytucji dialogu społecznego, ale rozpowszechnione są tzw. przetargi taryfowe (Tarifvertragen) w gospodarce, a regionalne reprezentacje w wyższej izbie parlamentu są niejednokrotnie rzecznikami interesów lokalnych, przede wszystkim gospodarczych, a w mniejszym zakresie społecznych. W efekcie na niemiecką wyższą izbę parlamentu większe przełożenie mają organizacje pracodawców i biznesowe. To właśnie one mogą grać parlamentarnym wetem. Natomiast związki zawodowe są silne w zakładach pracy, w przetargach taryfowych, zwłaszcza w niektórych branżach, np. tradycyjnie w przemyśle metalurgicznym. Rzecz jasna, niemieckie związki zawodowe bywają też

${ }^{13}$ K. Kichewko, Polityka publiczna w partnerstwie - nowa Irlandzka Umowa Centralna (Lansdowne Road Agreement), „Studia z Polityki Publicznej” 2016, nr 3, s. 79.

${ }^{14}$ F.W. Scharpf, The Joint-Decision Trap: Lessons from German Federalism and European Integration, „Public Administration” 1988, nr 3, s. 239.

${ }^{15}$ Korporatyzm i pluralizm to dwa wiodące w powojennej Europie Zachodniej instytucjonalne warianty oddziaływań organizacji grup interesu na decyzje publiczne. W korporatyzmie przeważają większe organizacje, którym umożliwia się bezpośredni i — za sprawą instytucji dialogu społecznego parytetowy udział w kształtowaniu polityki publicznej państwa. Najsilniejsze z tych organizacji to centrale związków zawodowych oraz zrzeszenia pracodawców i przedsiębiorców. Natomiast w pluralizmie rozwiązań tego typu się nie stosuje lub stosuje się je w ograniczonym zakresie. Dominuje w nim lobbing jako forma oddziaływania na decyzje publiczne, a organizacje grup interesu są bardziej rozczłonkowane. W poszczególnych krajach rozwiązania instytucjonalne zmieniały się, sytuując się bliżej modelowego pluralizmu bądź korporatyzmu. Generalnie różne formy korporatyzmu dominowały w Europie kontynentalnej, a pluralizm jest typowy dla Wielkiej Brytanii. W Polsce ukształtowała się chwiejna, etatystyczna forma korporatyzmu. Więcej na ten temat vide J. Sroka, Europejskie stosunki przemystowe w perspektywie porównawczej, Wrocław 2000, s. 54-98. 
silne na ulicy, wciąż mają moc organizowania masowych pikiet czy manifestacji, co stanowi o pozaparlamentarnym potencjale gry wetem. Dla ścisłości oraz pełnego obrazu sytuacji dialogowej w Niemczech należy jednak pamiętać o generalnie nadal wyraźnie utrzymującej się koncyliacyjnej — zwłaszcza na tle sytuacji w takich krajach, jak Polska — orientacji tamtejszych organizacji partnerów społecznych. Dzięki niej wciąż możliwe jest w Niemczech praktykowanie unikalnej w skali świata, pozaprawnej, dobrowolnej, a zarazem daleko idącej formuły współpracy w formie tzw. akcji skoncentrowanej (Konzentierte Aktion $)^{16}$. W Polsce pułapka wspólnych decyzji działa zdecydowanie silniej niż $\mathrm{w}$ Niemczech, a dodatkowym utrudnieniem jest rozwojowa blokada $\mathrm{w}$ formie pułapki średnich dochodów. Wiedzą o tym - albo raczej odczuwają to - wszystkie strony zaangażowane w polski dialog, które na przemian uciekają się do gry wetem, blokowania decyzji, zrywania obrad oraz innych form działań kolizyjnych i konfrontacyjnych.

Deliberacja - podążając za wspomnianym wcześniej przykładem irlandzkim — stwarza najbardziej realną szansę na przezwyciężenie obu wspomnianych pułapek, tj. pułapki średnich dochodów oraz pułapki wspólnych decyzji. Jej praktykowanie nie jest jednak łatwe. Jedynie pozornie mogłoby się wydawać, że w Polsce, np. z uwagi na doświadczenia najnowszej historii, praktyki dialogu i współdecydowania miały - a nawet może mają nadal - sprzyjające warunki rozwojowe. Niestety, choć były inicjowane od początku lat dziewięćdziesiątych, wciąż słabo się rozwijają. Świadczą o tym umiarkowane rezultaty oficjalnie promowanego dialogu społecznego, który współcześnie uosabia Rada Dialogu Społecznego i wojewódzkie rady dialogu społecznego ${ }^{17}$, oraz - wprawdzie nieco mniej hołubionego, ale jednak w porównaniu $\mathrm{z}$ innymi formami partycypacji — wyraźniej wspomaganego dialogu obywatelskiego ${ }^{18}$. Obu formom dialogowym to wspomaganie nie wychodziło na dobre w tym sensie, że wspierane w sposób partyjno-polityczny jednocześnie kulturowo i społecznie karlały ${ }^{19}$. $\mathrm{W}$ imię doraźnych zysków - owszem, niekiedy sytuacyjnie doniosłych, jak w poszczególnych przypadkach zarządzania poziomem konfliktów przemysłowych czy zarządzania kryzysowego - generalnie zaprzepaszczano szanse na prodeliberacyjne, etapowe przemodelowywanie kultury politycznej. Kontraktowanie pokoju społecznego z poszczególnymi partnerami społecznymi zawsze przebiegało w konfiguracjach zależnych od aktualnego układu koalicyjnego na forum parlamentu. Zatem nie ze

16 Vide J. Sroka, Polityka organizacji pracodawców i przedsiębiorców, Wrocław 2004, s. 132-138; idem, Europejskie stosunki przemystowe..., s. 84-87.

${ }_{17}$ Ustawa z dnia 24 lipca 2015 r. o Radzie Dialogu Społecznego i innych instytucjach dialogu społecznego, Dz.U. z 2015 r. poz. 1240.

${ }^{18}$ Ustawa z dnia 24 kwietnia 2003 r. o działalności pożytku publicznego i wolontariacie, Dz.U. z 2003 r. nr 96, poz. 873.

19 Vide A. Bejma, Organizacje pozarzadowe jako podmioty zarzadzania publicznego, [w:] Nowe idee zarzadzania publicznego. Wyzwania i dylematy, red. E.M. Marciniak, J. Szczupaczyński, Warszawa 2017, s. 211; J. Sroka, Analiza funkcjonowania instytucji dialogu społecznego na poziomie województw. Raport z badań wojewódzkich komisji dialogu społecznego, Warszawa 2009, s. 6 i n.; idem, Konfliktowy elityzm grup interesów zamiast społeczeństwa obywatelskiego? Przyczynek do analizy systemowej, [w:] Demokracja polska na poczatku drugiej dekady XXI wieku, red. Z. Machelski, Opole 2013, s. 105. 
wszystkimi i nie zawsze prowadzono dialog i dochodzono do konstruktywnych konkluzji. Nie ze wszystkimi i nie zawsze, ponieważ operacjonalizowano spolaryzowany ze swej natury potencjał polityczny, który przyciągał do siebie odpowiednie bieguny polaryzacji także spośród partnerów społecznych, np. te, które reprezentują dwie historyczne centrale związkowe: Niezależny Samorządny Związek Zawodowy „Solidarność" oraz Ogólnopolskie Porozumienie Związków Zawodowych. Kapitalizując takie biegunowe, partyjno-społeczne koalicje, coraz bardziej zaprzepaszczano szanse inwestowania w kapitał społeczny w takim znaczeniu tego pojęcia, o jakim możemy poczytać choćby w kolejnych opracowaniach Diagnozy spolecznej ${ }^{20}$.

$\mathrm{W}$ obu przypadkach, $\mathrm{tj}$. dialogu społecznego i dialogu obywatelskiego, przyjmowano odpowiednie akty prawne, nadając obu formom dialogowym formalnie coraz wyższy status. Niestety, oba dialogi, społeczny i obywatelski, nie przekształciły się w deliberację, ale utknęły na mieliznach mocno okrojonych konsultacji przeddecyzyjnych, realizowanych w ramach tradycyjnych form elitarnej reprezentacji interesów, tj. z przewagą strony rządowej, która w mniej lub bardziej uogólniony sposób korzysta z poparcia większości parlamentarnej. Dialogowe rozwiązania instytucjonalne funkcjonalnie usprawniły nieco system, stworzyły dodatkowe zabezpieczenia dla pokoju społecznego, stworzyły swoiste systemowe wentyle bezpieczeństwa. Ale nie stworzono nowej jakości w wymiarze kulturowo-instytucjonalnym. Mając na uwadze przeszłe losy obu form dialogowych, a także ich teraźniejszość, nie sposób stwierdzić inaczej, jak tylko że w Polsce nie rozwija się deliberacja. Rozwija się jedynie jej ersatz $\mathrm{w}$ formie chwiejnych, niesamodzielnych i upolitycznionych oraz wciąż bardzo słabo kulturowo zinstytucjonalizowanych namiastek: dialogu społecznego i dialogu obywatelskiego. Sporo na ten temat już napisano, może nie aż tyle, aby problematyka ta była w społeczeństwie szeroko znana, bo to po prostu niemożliwe, ale tekstów analityczno-diagnozujących i zawierających rekomendacje jest aż nadto, aby odeprzeć ewentualny zarzut o słabym rozpoznaniu problematyki dialogu w Polsce.

\section{IV. „JALOWY BIEG” ROZWIĄZAŃ PARTYCYPACYJNYCH JAKO PRZEJAW ENTROPII SYSTEMOWEJ ${ }^{21}$}

Stosunkowo mniej uwagi poświęcono w polskich opracowaniach naukowych formalnie uregulowanemu już od 2005 r. lobbingowi ${ }^{22}$. O lobbingu w Polsce w sposób naukowy mówi się i pisze, ale rzadziej i zwykle w odniesieniu do tych form rzecznictwa interesów, które mają zastosowanie wobec instytucji Unii Europejskiej ${ }^{23}$. Pozostaje stwierdzić, że dzieje się tak nie tylko dlatego, że lobbing, podobnie jak pieniądze, „lubi

20 Vide J. Czapiński, Stan społeczeństwa obywatelskiego, [w:] Diagnoza społeczna. Warunki i jakość życia Polaków, red. J. Czapiński, T. Panek, Warszawa 2015, s. 332.

${ }^{21}$ W tej części artykułu został wykorzystany fragment monografii autora, vide J. Sroka, Współdecydowanie $w$ wielopasmowej..., s. 67.

22 Ustawa z dnia 7 lipca 2005 r. o działalności lobbingowej w procesie stanowienia prawa, Dz.U. z 2005 r., nr 169, poz. 1414.

${ }_{23}$ Vide U. Kurczewska, Lobbing i grupy interesu w Unii Europejskiej, Warszawa 2011, s. 13 i n.; J.F. Czub, Hybrydowy model funkcjonowania grup interesu w Unii Europejskiej, Warszawa 2018, s. 19 i n. 
ciszę" - jest to prawda jedynie po części. I to prawda bardziej dotycząca deformacji kojarzonych z lobbingiem niż samego precyzyjniej rozumianego lobbingu ${ }^{24}$, który rozwija się w Polsce słabo. W przypadku pokrewnego mu wysłuchania publicznego oraz konsultacji społecznych dominują raczej wypowiedzi administracyjno-prawnicze, wzbogacane niekiedy elementami historyczno-ustrojowymi bądź porównawczo-ustrojowymi ${ }^{25}$. W badaniach z zakresu nauk społecznych, na których skupiono niniejszą analizę, tematu tego nie podejmuje się nie z niechęci, ale z uwagi na miałkość dostępnego materiału. Mówiąc wprost, istniejące w Polsce odpowiednie rozwiązania prawne w praktyce nie zakorzeniły się na tyle, aby było co badać, a to, co w kontekście czy raczej w cieniu oficjalnego lobbingu ewentualnie się rozwija, badane $-\mathrm{z}$ definicji — być nie chce. Odsłanianiem arkanów takiego wpływu ,z półcienia” nie są zainteresowane podmioty uwikłane w tego typu relacje, za to ich badaniem co jakiś czas zajmują się specjalnie powoływane komisje śledcze. Akademicy ewentualnie badają efekty prac takich komisji ${ }^{26}$. W niniejszym artykule nie zostały one jednak poddane analizie z powodu jeszcze słabszego niż w przypadku dialogu społecznego i dialogu obywatelskiego kulturowo-instytucjonalnego uzasadnienia lobbingu, wysłuchania publicznego i konsultacji społecznych, co jest główną przyczyną ich niewielkiego funkcjonalnego zastosowania w polityce publicznej. Wspomniana słabość jedynie w niewielkiej części wynika z zainstalowania w polskim układzie instytucjonalnym mechanizmów korporatyzmu — zetatyzowanego i chwiejnego uosabianego współcześnie przez Radę Dialogu Społecznego. Nie można zatem odnieść do Polski stwierdzenia, wedle którego np. wysłuchanie publiczne ma małe znaczenie $\mathrm{z}$ takich powodów, jak np. w korporatystycznej Austrii ${ }^{27}$.

W Polsce niemoc tych elementów systemu instytucjonalnego, które składają się na jego współdecyzyjny potencjał, jest wielka. Potencjalnie elementy te w systemie istnieją, ale realnie wciąż pozostają na ,jałowym biegu”. Funkcjonalnie są mało przydatne, a niekiedy bywają nawet kontrproduktywne. Istnieje zatem duża niespójność między formalnymi i nieformalnymi wzorcami działań zorientowanych na wywieranie presji decyzyjnych w obszarze publicznym. O występowaniu w Polsce takiego rozziewu przekonują także wyniki badań, ekspertyzy oraz ich uogólnienia ${ }^{28}$. Świadczą one o utrzymującym się w Polsce wysokim poziomie entropii systemowej, zwłasz-

${ }^{24}$ Szerzej na ten temat vide: K. Jasiecki, M. Molęda-Zdziech, U. Kurczewska, Lobbing. Sztuka skutecznego wywierania wpływu, Kraków 2006, s. 7 i n.; J. Sroka, Lobbing jako strategia promocji interesów grupowych, [w:] Marketing polityczny w teorii i praktyce, red. A. Jabłoński, L. Sobkowiak, Wrocław 2009, s. 208.

25 Vide M. Borski, Wystuchanie publiczne - ważna, chociaż niedoceniana instytucja demokracji partycypacyjnej, „Roczniki Administracji i Prawa” 2016, nr 16, s. 32.

26 Vide A. Madera, Sejmowe komisje śledcze. Polskie tradycje i doświadczenia współczesne, Toruń 2011, s. 6 i n.; B. Secler, Sejmowe komisje śledcze w systemie politycznym RP. Bilans dotychczasowych doświadczeń, „Środkowoeuropejskie Studia Polityczne” 2013, nr 4, s. 209.

27 Confer G. Makowski, Instytucja wystuchania pub liczne go w Polsce, jako mechanizm partycypacji obywateli w procesie stanowienia prawa, [w:] Organizacje pozarzadowe. Dialog obywatelski. Polityka państwa, red. M. Rymsza, Warszawa 2007, s. 156.

${ }_{28}$ Vide Wybrane instytucje demokracji partycypacyjnej...; J. Sroka, Współdecydowanie w wielopasmowej... 
cza w tych fragmentach systemu, których funkcjonowanie formalnie związane jest ze współdecydowaniem.

Lobbing jako strategia promocji interesów wymaga stosunkowo prostszych parametrów instytucjonalnych niż w przypadku zinstytucjonalizowanego dialogu, a tym bardziej kulturowo i systemowo zakorzenionej deliberacji. Sprawy te były już omawiane w innych publikacjach, z których część uwzględniono w wykazie literatury dołączonym do niniejszego artykułu. Dość powiedzieć, że lobbing to strategia grup interesu charakterystyczna dla tzw. pluralistycznego układu instytucjonalnego, charakteryzującego się rywalizacyjnym stylem relacji oraz ich kontraktowością, ale — należy dodać — kontraktowością konsekwentną, nawiązującą do wolnorynkowego etosu purytańskiego mieszczaństwa. To właśnie dlatego lobbing wyraźniej rozwija się w Stanach Zjednoczonych Ameryki i Wielkiej Brytanii, jest słabszy w krajach kontynentalnej Europy Zachodniej, gdzie dominował konsensualny w swej istocie korporatyzm, a w krajach postkomunistycznych działania określane mianem lobbingu nierzadko z prawdziwym lobbingiem mają niewiele wspólnego.

Lobbing w konsekwentnym, ścisłym i pluralistycznym ujęciu nie oznacza każdego skutecznego działania we własnym interesie, podobnie jak — co dla szerszej publiczności bywa już bardziej jasne - nie każde działanie w interesie własnym może być uznane za obronę konieczną. W definicji lobbingu zupełnie nie mieszczą się takie strategie, jak korupcja, handel wpływami czy płatna protekcja, a mimo to praktyki te przez wielu są potocznie uznawane za synonimiczne dla lobbingu. Mając to na uwadze, należy po raz kolejny stwierdzić rzecz zupełnie już nieodkrywczą, że działające w Polsce media, kojarząc $\mathrm{z}$ lobbingiem szemrane działania prowadzone w półcieniu władzy czy kolejne afery związane z naciskiem interesów partykularnych na publiczne procesy decyzyjne, przyczyniają się do pogłębienia zamętu pojęciowego. Utrudnia on albo uniemożliwia odbiorcom percepcję procesu politycznego w kategoriach podobnych do tych, które są uznawane przez społeczeństwa dłużej praktykujące systemy otwarte.

„Lobbing to przede wszystkim strategia uprzedzająca, polegająca głównie na sztuce perswazji, przekonywania osób, w gestii których leżą decyzje polityczne i administracyjne, o potrzebie wzięcia pod uwagę określonych interesów grupowych. Lobbyści starają się przedstawić swoje racje w taki sposób, aby odbiorcy ich «produktów» byli przekonani, że dokonali dobrej transakcji. Zasadniczym narzędziem lobbyingu są zatem, w odpowiedni sposób «spreparowane», informacje, którym towarzyszą zasoby o innym charakterze" ${ }^{29}$.

Jedną z istotnych możliwości prowadzenia działalności lobbystycznej, zwłaszcza na forum parlamentu, stanowi wysłuchanie publiczne. Formuła wysłuchania publicznego jest stosunkowo prosta, nie wymaga specjalnych nakładów i skomplikowanych procedur ani też wyższego niż podstawowy poziomu uogólnionego zaufania. Wystarczy zachować odpowiedni poziom przejrzystości i uczciwości relacji między stronami biorącymi udział w wysłuchaniu publicznym. W zasadzie nie sposób charakteryzować

29 J. Sroka, Lobbing jako strategia..., s. 219. 
wysłuchanie publiczne bez nawiązywania do lobbingu, ale warto pamiętać, że ma ono wyraźne cechy własne, jak m.in.: reprezentatywność, niezależność, wczesne zaangażowanie, przejrzystość, dostępność informacji, jasność procedur czy efektywność ze względu na koszty ${ }^{30}$. Już skrótowy przegląd tych cech przekonuje, że wysłuchanie publiczne - mimo wspomnianych stosunkowo niewielkich wymagań — potrzebuje jednak pewnego zakorzenienia oraz odpowiedniego poziomu kultury obywatelskiej, politycznej, administracyjnej czy prawnej. Wysłuchanie publiczne jest więc spowinowacone $\mathrm{z}$ lobbingiem, a także $\mathrm{z}$ prawem do petycji ${ }^{31}$, ale jednocześnie jest wobec nich autonomiczne, choć w Polsce początkowo było formalnie utożsamiane z lobbingiem ${ }^{32}$. Jego częste wykorzystywanie obok, a nie zamiast innych mechanizmów partycypacji w decydowaniu publicznym świadczy o większej otwartości systemu. W Polsce z rozwiązania tego korzysta się jednak rzadko i nie wynika to z korporatyzacji systemu, ponieważ korporatyzm jest $\mathrm{w}$ naszym kraju chwiejny i zetatyzowany.

Naocznym i rażącym przykładem ,jałowego biegu” w praktycznym funkcjonowaniu rozwiązań partycypacyjnych w Polsce jest obraz brzydkich polskich przedmieść. To oczywiście jedynie hasło, ponieważ chodzi o problem znacznie szerszy, nieodnoszący się jedynie do przedmieść, ale generalnie do chaotycznego zagospodarowania przestrzennego, które wynika m.in. z wadliwego korzystania ze znanej z ustawy o samorządzie terytorialnym formuły konsultacji społecznych lub niekorzystania z niej $\mathrm{w}$ istocie wcale. W 2018 r. partycypacyjne rozwiązania samorządowe zostały uzupełnione m.in. o ramową regulację tzw. budżetu obywatelskiego ${ }^{33}$. Entropii systemowej to jednak nie zmniejszyło, o czym przekonują komentarze prawne ${ }^{34}$, a w zakresie zagospodarowania przestrzennego nie zmienia się nic.

Rozrastające się - w wielu przypadkach nieestetyczne i niefunkcjonalne przedmieścia są naocznym efektem deficytu kooperacji. W tym sensie współczesne polskie suburbia to rażące symptomy wielkiego nieporozumienia społecznego. Jego przyczyny wynikają nie tylko z niedorozwoju mechanizmów partycypacyjnych, które mogłyby prawdziwie angażować społeczności lokalne w deliberację i współdecydowanie - to jedynie formalny rezultat uwarunkowań kulturowo-instytucjonalnych, które spowalniają bądź uniemożliwiają rozwój kulturowo uzasadnionych, partycypacyjnych form kształtowania przestrzeni publicznej. Chaos polskich przedmieść jest odzwierciedleniem społecznego stanu splątania, który uniemożliwia spójne łączenie wątków indywidualnych i kolektywnych. Niejasne skłębienie ulic odpowiada niejasności intencji. W tym sensie brzydota przedmieść świadczy o brzydocie relacji.

${ }^{30}$ Więcej na ten temat vide G. Rowe, L.J. Frewer, Public Participation Methods: A Framework for Evaluation, „Science, Technology \& Human Values” 2000, nr 1, s. 3.

31 Vide Ustawa z dnia 11 lipca 2014 r. o petycjach, Dz.U. z 2018 r., poz. 870.

32 M. Wiszowaty, Ustawa o działalności lobbingowej w procesie stanowienia prawa, „Przegląd Sejmowy" 2006, nr 5, s. 41.

${ }^{33}$ Ustawa z dnia 11 stycznia 2018 r. o zmianie niektórych ustaw w celu zwiększenia udziału obywateli w procesie wybierania, funkcjonowania i kontrolowania niektórych organów publicznych, Dz.U. z 2018 r. poz. 130.

${ }^{34}$ D. Sześciło, Nowe narzędzia dla obywateli i radnych w samorzadzie, Warszawa 2018, s. 1. 
Przyczyną chaosu wielu polskich przedmieść jest powszechne niezrozumienie idei partycypacyjnej przestrzeni publicznej, za czym idą oderwane od tej idei konkretne praktyki zagospodarowania przestrzennego, które znamy z codzienności. Emitowany przez instytucje UE wzorzec partycypacyjnej przestrzeni publicznej jest w Polsce zniekształcany nie tylko ze względu na niezrozumienie samej idei, zwykłego braku chęci czy nierzadko spotykanego braku konsekwencji władz, ale także ze względu na zamieszanie powodowane wielokierunkowymi oddziaływaniami lokalnych grup interesu, które ponad dialogową partycypację przedkładają bliższy rodzimej kulturze rywalizacyjny wariant oddziaływań nieformalnych. W sferze politycznej jednym z głównych tego efektów jest powstawanie koalicji dystrybucyjnych łączących grupy interesu z decydentami publicznymi. W sferze społecznej prowadzi to do kartelizacji i narastania dysfunkcji przestrzeni publicznej, natomiast w sferze przestrzenno-estetycznej do dysfunkcjonalności, brzydoty i groteskowości, które wyzierają z obrazu wielu polskich miejscowości. W tym sensie brzydkie przedmieścia ze swoją kuriozalną niekiedy architekturą, chwiejną niby-tożsamością i specyfiką lokalnych wcieleń polityki publicznej, są częścią współczesnej kultury popularnej, w której jak w krzywym zwierciadle odbija się ułomny obraz idei partycypacyjnej przestrzeni publicznej i partycypacji w ogóle. Skoro zatem architektura estetycznie oddaje ducha czasu - podobnie jak światopoglądowo czynią to ideologie, quasi-ideologie oraz nie-ideologie - to proces jej powstawania, jej ewolucja zarówno w przedmiocie, jak i w formie oraz w kompozycji są równie dobrymi obiektami diagnozowania realnych stosunków władczych oraz stanu sieci społecznych.

Projektowanie przestrzeni publicznej to problem polityczny, a chaos w przestrzeni publicznej odzwierciedla w Polsce brak koordynacji i rywalizacyjność w polityce publicznej na poziomie lokalnym i ponadlokalnym. Taka perspektywa faworyzuje podejście przedmiotowe i spycha $\mathrm{w}$ cień procesulane podejście do przestrzeni publicznej ${ }^{35}$. W praktyce oznacza to odrzucenie idei, aby ta przestrzeń sama w sobie stawała się partycypacyjna. Brak wystarczająco silnych orientacji partycypacyjnych na poziomie lokalnym, w lokalnej tożsamości nie dziwi, jeśli uwzględnimy, że „,kluczowa dla zrozumienia fenomenu lokalnej, miejskiej oraz regionalnej tożsamości jest teza, iż tożsamość ta jest produktem społecznym. Wykuwa się w społecznym dyskursie, przejmując tak cechy tego dyskursu, jak i praktyk społecznych, które ten dyskurs organizują. Tożsamość jest konstruktem będącym następstwem skomplikowanej gry wyrażonych w różnych narracjach interesów artykułowanych przez różnych aktorów miejskiej sceny" ${ }^{\text {"36 }}$. Jednocześnie ,indywidualizm, prywatność i własność to, sądząc po kształcie osiedli podmiejskich w Polsce, najistotniejsze wartości, jakim hołdują ich mieszkańcy. Brak przestrzeni publicznych dodatkowo wzmacnia ich postawy. [...] U mieszkańców nowych osiedli podmiejskich można zauważyć strategię oswajania przestrzeni pozadomowej, polegającą na zindywidualizowanym poznawaniu i oswajaniu lokalnie atrakcyjnych

35 P. Jaworski, Przestrzeń radykalnej demokracji, „Autoportret. Pismo o Dobrej Przestrzeni” 2012, nr 2, s. 17.

${ }^{36}$ M. Błaszczyk, O politycznej naturze tożsamości lokalnej, [w:] Społeczne i ekonomiczne aspekty urbanizacji i metropolizacji, red. M. Malikowski, M. Palak, J. Halik, Rzeszów 2015, s. 35. 
miejsc [...] traktowaniu ich jako prywatnych miejsc magicznych, a nie miejsc publicznych — współdzielonych i współdoświadczanych z innymi mieszkańcami”’”${ }^{37}$.

Sytuacji tej nie polepszają, a wręcz utrwalają tzw. konsultacje z mieszkańcami w sprawach związanych z zagospodarowaniem. „Problemem jest zwykle to, że konsultacje pojawiają się późno, kiedy projekt planu miejscowego jest już gotowy, uzgodniony i zaopiniowany. Mieszkańcy spotykają się z urbanistami i urzędnikami, zaczyna się więc swoista gra: stronie samorządowej zależy na tym, żeby nie powtarzać procedury, która przekreśli sens podjętych do tej pory prac, a mieszkańcy z kolei — zaskoczeni ustaleniami - zaczynają coraz bardziej nerwowo dopytywać o to, kto i dlaczego tak je sformułował. Odpowiedzi, które padają, często rodzą frustrację"38.

Taka praktyka partycypacji nie prowadzi do niczego nowego. Nie towarzyszy jej dążenie do stworzenia realnej, systemowej areny, na której mogą zostać skonfrontowane różnice i powzięte działania na rzecz wspólnego wypracowania rozwiązań. $\mathrm{Na}$ to potrzeba czasu i chęci, ale przede wszystkim przydaje się nieco wyobraźni. Niestety deliberacja nie zaistniała tymczasem w rodzimym imaginarium społecznym, gospodarczym ani politycznym. I nie będzie mogła zaistnieć, dopóki nie pojawi się kulturowa podstawa kształtująca świadomość, że w przestrzeni między stabilnością a niestabilnością systemową można lepiej nawigować, posługując się deliberacją niż eksploatując dotychczasowe metody konfrontacji stanowisk, których wspólny mianownik zbiega się w polityce partyjnej. Deliberacja sprawia, że charakterystyczne dla demokracji próby negocjowania z systemem w sprawach korzyści grupowych mogą być obsługiwane zanim zostaną przechwycone i zagospodarowane przez politykę partyjną. W efekcie obniżają się koszty transakcji i opada poziom emocji, co sprzyja wymianie myśli oraz ewolucji poglądów na temat dyskutowanych spraw publicznych. Powtarzalność i rozproszenie takich deliberacyjnych cyklów kształtuje i utrwala kooperacyjne wzorce kulturowe, które działając zwrotnie, zamykają samoreferencyjny, czyli autopojetyczny $\left(\right.$ autopiesis $^{39}$ ), tzn. samowytwarzający się obieg systemowo-polityczny.

\section{ZAKOŃCZENIE}

Podsumowując, w praktyce krajowej nadal przeważają stare, partyjno-polityczne sposoby agregacji problemów wprowadzanych do agendy polityki publicznej. Wciąż utrzymuje się deficyt współdecydowania. Przytoczone przykłady obniżonej partycypacji obywateli w podejmowaniu decyzji publicznych nie wyczerpują tematu. Jest ich o wiele więcej, a tylko niektóre $z$ nich są badane i opisywane. O jednym $\mathrm{z}$ takich przykładów traktuje pogłębione studium polskiego programu atomowego ${ }^{40}$, ukazujące znikomy udział obywateli w zarządzaniu jednym z kluczowych sektorów

${ }^{37}$ K. Kajdanek, op. cit.

${ }^{38}$ Ł. Drozda, Partycypacja w planowaniu przestrzeni się opłaca! — wywiad z Pawłem Jaworskim, $<$ http://partycypacjaobywatelska.pl/wywiad-z-pawlem-jaworskim>, dostęp 28 II 2019.

${ }^{39}$ Więcej na ten temat vide np.: M. Brans, S. Rossbach, The Autopoiesis of Administrative Systems: Niklas Luhmann on Public Administration and Public Policy, „Public Administration” 1997, nr 3, s. 417 i n.

40 Vide P. Stankiewicz, Gra w atom. Społeczne zarzadzanie technologia w rozwoju energetyki jądrowej $w$ Polsce, Toruń 2017, s. 241 i n. 
sfery $\mathrm{B}+\mathrm{R}$, co stanowi kolejny dowód na poważne zapóźnienie polskich zmian modernizacyjnych. Pułapka rozwojowa jest faktem, tkwimy w niej i niestety, jak się wydaje, tkwić będziemy, jeśli naprawdę nie postawimy na deliberację. Nie uda się bowiem przełamać barier starymi, hierarchicznymi sposobami. Nie będzie to możliwe również jedynie za sprawą namysłu parlamentarnej reprezentacji, choćby namysł ten był jak najgłębszy i wolny od bastionowo-partyjnego nalotu, co jest, jak wiemy, właściwie niewykonalne. W wielu współczesnych reprezentacjach parlamentarnych, również w polskiej, zbyt często i zbyt mocno daje o sobie znać polaryzacja afektywna, która przekreśla szanse na pozbycie się wspomnianego nalotu. Najlepszym sposobem na łagodzenie biegunowości afektów jest prawdziwa deliberacja - prowadzona nie na forum parlamentu, ponieważ jego skład jest ze swej natury polityczno-partyjny, a więc potencjalnie konfrontacyjny i debaty są w takich warunkach siłą rzeczy upolitycznione, ale deliberacja obywatelska, która powinna być niewymuszona i nieformalna, a jednocześnie rozpowszechniona w wielu formalnych rozwiązaniach systemowych. Chodzi więc o deliberację zakorzenioną kulturowo, praktykowaną możliwie najczęściej i w wielu miejscach zarówno w sensie topograficznym, jak i systemowym. Natomiast hierarchiczny aparat wykonawczy jest trwale obciążony wadami modelu Weberowskiego, które - mimo że są dobrze znane oraz były i są wielokrotnie opisywane ${ }^{41}$ - są jednak nie do usunięcia. Można je natomiast redukować mechanizmami partycypacyjnymi. Można, ale praktykowanie takich rozwiązań jest nieporównanie trudniejsze, niż ich uchwalanie. Dlatego wciąż utrzymuje się stan podwyższonej entropii systemowej wynikający z pozostawania polskich rozwiązań partycypacyjnych na ,jałowym biegu”. Nie jesteśmy w tym osamotnieni, podobna sytuacja utrzymuje się m.in. we współczesnej Grecji i Portugalii oraz w większości krajów Europy Środkowej i Wschodniej. Chociaż wydaje się, że niektóre z tych krajów, a w szczególności Słowenia ${ }^{42}$, wychodzą z tej rozwojowej pułapki. Pomaga w tym praktykowanie rozwiązań deliberacyjnych.

\section{BIBLIOGRAFIA}

\section{ŹRÓDŁA}

Ustawa z dnia 24 kwietnia 2003 r. o działalności pożytku publicznego i wolontariacie, Dz.U. z 2003 r. nr 96, poz. 873.

Ustawa z dnia 7 lipca 2005 r. o działalności lobbingowej w procesie stanowienia prawa, Dz.U. z 2005 r. nr 169, poz. 1414.

Ustawa z dnia 11 lipca 2014 r. o petycjach, Dz.U. z 2018 r. poz. 870.

Ustawa z dnia 11 lipca 2014 r. o zasadach realizacji programów w zakresie polityki spójności finansowanych w perspektywie finansowej 2014-2020, Dz.U. z 2014 r. poz. 1146.

Ustawa z dnia 24 lipca 2015 r. o Radzie Dialogu Społecznego i innych instytucjach dialogu społecznego, Dz.U. z 2015 r. poz. 1240.

Ustawa z dnia 22 grudnia 2015 r. o Zintegrowanym Systemie Kwalifikacji, Dz.U. z 2016 r. poz. 64.

${ }^{41}$ Vide np.: B.G. Peters, Administracja publiczna w systemie politycznym, Warszawa 1999, s. 249-295.

42 M. Caprile, P. Sanz, I. Riobóo, Ch. Welz, R. Rodríguez, Mapping varieties of industrial relations:

Eurofound's analytical framework applied, Luxembourg 2017, s. 5 i n. 
Ustawa z dnia 11 stycznia 2018 r. o zmianie niektórych ustaw w celu zwiększenia udziału obywateli w procesie wybierania, funkcjonowania i kontrolowania niektórych organów publicznych, Dz.U. z 2018 r. poz. 130.

Ustawa z dnia 20 lipca 2018 r. Prawo o szkolnictwie wyższym i nauce, Dz.U. z 2018 r. poz. 1668.

\section{PIŚMIENNICTWO}

Agénor P.R., Canuto O., Jelenic M., Avoiding Midle-Income Growth Trap, „Economic Premise” 2012, nr 98.

Bejma A., Organizacje pozarzadowe jako podmioty zarzadzania publicznego, [w:] Nowe idee zarządzania publicznego. Wyzwania i dylematy, red. E.M. Marciniak, J. Szczupaczyński, Dom Wydawniczy ELIPSA, Warszawa 2017.

Błaszczyk M., O politycznej naturze tożsamości lokalnej, [w:] Społeczne i ekonomiczne aspekty urbanizacji i metropolizacji, red. M. Malikowski, M. Palak, J. Halik, Wydawnictwo Uniwersytetu Rzeszowskiego, Rzeszów 2015.

Brans M., Rossbach S., The Autopoiesis of Administrative Systems: Niklas Luhmann on Public Administration and Public Policy, „Public Administration” 1997, nr 3, https://doi.org/10. 1111/1467-9299.00068.

Caprile M., Sanz P., Riobóo I., Welz Ch., Rodríguez R., Mapping varieties of industrial relations: Eurofound's analytical framework applied, Publications Office of the European Union, Luxembourg 2017.

Coelho V.S.P., A Brief Reflection on the Brazilian Participatory Experience, „Journal of Public Deliberation" 2014, nr 1.

Czapiński J., Stan społeczeństwa obywatelskiego, [w:] Diagnoza społeczna. Warunki i jakość życia Polaków, red. J. Czapiński, T. Panek, Rada Monitoringu Społecznego, Warszawa 2015.

Czub J.F., Hybrydowy model funkcjonowania grup interesu w Unii Europejskiej, Oficyna Wydawnicza ASPRA-JR, Warszawa 2018.

David P.A., Path dependence, its critics and the quest for 'historical economics', [w:] Evolution and Path Dependence in Economic Ideas: Past and Present, red. P. Garrouste, S. Ioannides, Edward Elgar Publishing, Cheltenham 2000.

Drozda Ł., Partycypacja w planowaniu przestrzeni się opłaca! — wywiad z Pawłem Jaworskim, $<\mathrm{http}: / /$ partycypacjaobywatelska.pl/wywiad-z-pawlem-jaworskim>.

Grönlund K., Herne K., Setälä M., Does Enclave Deliberation Polarize Opinions?, „Political Behaviors" 2015, nr 37, https://doi.org/10.1007/s11109-015-9304-x.

Hardin G., The Tragedy of the Commons, „Science. New Series” 1968, nr 3859.

Jasiecki K., Molęda-Zdziech M., Kurczewska U., Lobbing. Sztuka skutecznego wywierania wpływu, Oficyna Ekonomiczna, Kraków 2006.

Jaworski P., Przestrzeń radykalnej demokracji, „Autoportret. Pismo o Dobrej Przestrzeni” 2012, $\mathrm{nr} 2$.

Kajdanek K., Dlaczego polskie przedmieścia sa tak chaotyczne i brzydkie?, <https://wszystkoco najwazniejsze.pl.>

Kichewko K., Polityka publiczna w partnerstwie - nowa Irlandzka Umowa Centralna (Lansdowne Road Agreement), „Studia z Polityki Publicznej” 2016, nr 3.

Kurczewska U., Lobbing i grupy interesu w Unii Europejskiej, PWN, Warszawa 2011.

Madera A., Sejmowe komisje śledcze. Polskie tradycje i doświadczenia współczesne, Wydawnictwo A. Marszałek, Torun 2011.

Maia R.C.M., Danila C., Bargas J.K.R., Oliveira V.V., Rossini P.G.C., Sampaio R.C., Authotrity and Deliberative Moments: Assessing Equality and Inequality in Deeply Divided Groups, „Journal of Public Deliberation” 2017, nr 2.

Mansbridge J.J., Flaster K., The Cultural Politics of Everyday Discourse: The Case of "Male Chauvinist”, „Critical Sociology” 2007, nr 33, https://doi.org/10.1163/156916307x210973. 
Makowski G., Instytucja wystuchania publicznego w Polsce, jako mechanizm partycypacji obywateli w procesie stanowienia prawa, [w:] Organizacje pozarzadowe Dialog obywatelski Polityka państwa, red. M. Rymsza, Instytut Spraw Publicznych, Warszawa 2007.

Nölke A., Vliegenjhart A., Enlarging the Varietes of Capitalism: The emergence of dependent market economies in East Central Europe, „World Politics” 2009, https://doi.org/10.1017/ s0043887109990098.

Peters B.G., Administracja publiczna w systemie politycznym, Wydawnictwo Scholar, Warszawa 1999.

Pierson P., Increasing Returns, Path Dependence and the Study of Politics, „American Political Science Review” 2000, nr 2, https://doi.org/10.2307/2586011.

Rapacki R., Czwarta rewolucja przemysłowa a kierunki ewolucji kapitalizmu patchworkowego w Polsce, [w:] Świat (bez) pracy. Od Fordyzmu do czwartej rewolucji przemystowej, red. J. Czarzasty, Cz. Kliszko, Oficyna Wydawnicza SGH, Warszawa 2018.

Rowe G., Frewer L.J., Public Participation Methods: A Framework for Evaluation, „Science, Technology \& Human Values" 2000, nr 1, https://doi.org/10.1177/016224390002500101.

Secler B., Sejmowe komisje śledcze w systemie politycznym RP. Bilans dotychczasowych doświadczeń, „Środkowoeuropejskie Studia Polityczne” 2013, nr 4, https://doi.org/10.14746/ ssp.2013.4.13.

Sroka J., Europejskie stosunki przemysłowe w perspektywie porównawczej, Wydawnictwo Uniwersytetu Wrocławskiego, Wrocław 2000.

Sroka J., Polityka organizacji pracodawców i przedsiębiorców, Wydawnictwo Uniwersytetu Wrocławskiego, Wrocław 2004.

Sroka J., Deliberacja i rzadzenie wielopasmowe, Wydawnictwo Uniwersytetu Wrocławskiego, Wrocław 2009.

Sroka J., Lobbing jako strategia promocji interesów grupowych, [w:] Marketing polityczny w teorii i praktyce, red. A. Jabłoński, L. Sobkowiak, Wydawnictwo Uniwersytetu Wrocławskiego, Wrocław 2009.

Sroka J., Konfliktowy elityzm grup interesów zamiast społeczeństwa obywatelskiego? Przyczynek do analizy systemowej, [w:] Demokracja polska na początku drugiej dekady XXI wieku, red. Z. Machelski, Wydawnictwo Uniwersytetu Opolskiego, Opole 2013.

Sroka J., Rekomendacje w zakresie zasad włączania interesariuszy do wspótpracy zmodernizowanym Systemie Kwalifikacji (Rada Interesariuszy), Instytut Badań Edukacyjnych, Warszawa 2015.

Sroka J., Czy nieformalne wzorce kulturowe oraz formalne instytucje nadązaja za potrzeba partnerstwa $i$ dialogu? Czy i ewentualnie w jaki sposób można wzmacniać potencjat strony społecznej $w$ ramach partnerstwa $i$ dialogu $w$ europejskich funduszach strukturalnych i inwestycyjnych?, ekspertyza przygotowana na zlecenie dolnośląskiej Wojewódzkiej Rady Dialogu Społecznego, maszynopis powielony, Wrocław 2016.

Sroka J., Dialog w nauce i o nauce - o ograniczeniach polityki naukowej, „Cywilizacja i Polityka" 2017, nr 15, https://doi.org/10.5604/01.3001.0010.5458.

Sroka J., Współdecydowanie w wielopasmowej polityce publicznej, Dom Wydawniczy ELIPSA, Warszawa 2018.

Stankiewicz P., Gra w atom. Społeczne zarzadzanie technologia w rozwoju energetyki jadrowej w Polsce, Wydawnictwo Naukowe Uniwersytetu Mikołaja Kopernika, Toruń 2017.

Sześciło D., Nowe narzędzia dla obywateli i radnych $w$ samorzadzie, Fundacja im. Stefana Batorego, Warszawa 2018.

Wiszowaty M., Ustawa o działalności lobbingowej w procesie stanowienia prawa, „Przegląd Sejmowy" 2006, nr 5.

Wybrane instytucje demokracji partycypacyjnej w polskim systemie politycznym, Instytut Pracy i Spraw Socjalnych, red. J. Sroka, Warszawa 2008. 